Génét., Sél. Evol., 198315 (4), 519-532

\title{
Production of viable hybrids in salmonids by triploidization
}

\author{
B. CHEVASSUS, R. GUYOMARD, D. CHOURROUT \\ and Edwige QUILLET* \\ with the technical assistance of G. Burger and A. Devaux \\ I.N.R.A., Laboratoire de Physiologie des Poissons, F 78350 Jouy-en-Josas \\ *C.N.E.X.O., Centre Océanologie de Bretagne, F 29273 Brest Cedex
}

\begin{abstract}
Summary
Rainbow trout eggs were fertilized with milt collected from various salmonids (brown trout Salmo trutta; brook trout Salvelinus fontinalis; coho salmon Oncorhynchus kisutch) and heat-shocked few minutes later in order to prevent the second polar body extrusion. This operation resulted in high survival rates after 161 days : respectively 49.2 p. 100, 66.2 p. 100 and 12.5 p. 100 of the diploid rainbow trout control (basis 100 p. 100); the triploid hybrid constitution of these fish was ascertained by karyological and biochemical investigations.

These data contrast with the bad yields of the corresponding diploid hybridizations (no heat shock) respectively 0 p. $100,12.3$ p. 100 and 0 p. 100.

Such triploid hybrid salmonids, that are easy to produce, could be sterile and consequently of a great interest in aquaculture, where fish reproduction often makes the profitability decrease.
\end{abstract}

Key words : Hybrids, triploids, salmonids.

\section{Résumé}

Production d'hybrides viables chez les salmonidés par triplö̈disation

Des ovules de truite arc-en-ciel Salmo gairdneri ont été inséminés par du sperme de divers salmonidés (truite fario Salmo trutta; omble de fontaine Salvelinus fontinalis; saumon coho Oncorhynchus kisutch) puis soumis à un choc thermique chaud induisant la rétention du $2^{\mathrm{e}}$ globule polaire. Des individus viables ont été obtenus à un taux élevé : les taux de survie à 161 jours rapportés au témoin diploïde arc-en-ciel s'élèvent respectivement à 49,2 p. $100,66,2$ p. 100 et 12,5 p. 100 . Les données caryologiques et biochimiques indiquent que tous ces animaux sont des hybrides triplö̈des. Par contre, les mêmes croisements non soumis à un choc chaud ne produisent qu'un très faible nombre de survivants (respectivement 0 p. $100,12,3$ p. 100, 0 p. 100) identifiés comme des hybrides diploïdes. Compte tenu de leur facilité d'obtention, les hybrides triploïdes peuvent se révéler des animaux intéressants pour l'aquaculture, du fait notamment de leur éventuelle stérilité.

Mots clés : Hybrides, triplö̈des, salmonidés. 


\section{Introduction}

Natural occurrence of triploid adults in fishes was evidenced in rainbow trout Salmo gairdneri (Cuellar \& Uyeno, 1972 ; ThORgaARd \& Gall, 1979) and in Poecilia formosa (SAlSANo et al., 1972). In the case of an interspecific hybridization leading to a low survival rate, the frequency of allotriploidy among survivors sometimes seems to be very high, as demonstrated by CapanNa et al. (1974) in Salmo gairdneri $\times$ Salvelinus fontinalis hybrids, by MARIAN \& KRASZNAI (1978) and VASILEV et al. (1975) in some cyprinids. Besides, in the former and the latter case, the karyotype of those allotriploids clearly indicates a doubling of the maternal chromosome set.

In order to extend these observations, it seemed to be of great interest to induce a triploidization of diploid hybrid germs liable to early abortion. Triploidization techniques consist in applying thermal treatments to the eggs a few minutes after fertilization, in order to prevent the second polar body extrusion; in that way, high rates of triploidy were obtained in pure species (SWARUP, 1958, in stickleback ; Valenti, 1975, in Tilapia ; OJima \& MaKino, 1978, in common carp ; Chourrout, 1980, Chourrout \& Quillet, 1982, in rainbow trout) and in interspecific viable hybrids (Purdom, 1972 in flatfishes). In the present studies, unviable hybridizations in salmonids were taken as a model.

\section{Material and methods}

\section{A. Fertilization procedure}

Eggs from 12 female rainbow trouts, Salmo gairdneri (GAT78-I.N.R.A. strain) were sampled by abdominal pressure, mixed and distributed into four groups of about 1500 eggs. Each group was fertilized by a sperm mixture from 3 to 6 males of the following species :

- rainbow trout Salmo gairdneri (RA groups),

- brown trout Salmo trutta (BW groups),

- brook trout Salvelinus fontinalis (BO groups),

- Coho salmon Oncorhynchus kisutch (CS groups).

After mixing sperm and eggs, $50 \mathrm{~cm}^{3}$ of a saline buffered diluent was added (BILlaRd, 1977). Fifteen min. after, the inseminated eggs were transferred in normal freshwater for incubation in a recirculating system stabilized at $10^{\circ} \mathrm{C} \pm 0,5^{\circ} \mathrm{C}$.

\section{B. Thermal shock}

The triploidization treatment used was one of those described by CHOuRRouT \& Quiller (1982) : Twenty five min. after the beginning of incubation, a part of each group was transferred for twenty min. in a $26^{\circ} \mathrm{C}$ water bath, then put back directly into the incubation system. The rest of the eggs were kept as diploid controls.

\section{Incubation and larval rearing}

At the end of the incubation period (eyed stage : about 25 days at $10^{\circ} \mathrm{C}$ ), 
fertilized eggs were numbered and transferred into the experimental fish farm of GouRNAY, where early survival rates were studied up to 161 days after fertilization.

\section{Karyological methods}

Karyological investigations were performed on embryos at the tailbud stage (day 17) in the RA and CS groups, and on three month-old fingerlings in the RA2, $\mathrm{BO} 2, \mathrm{RA} 3$ and BW3 groups :

\section{Embryos}

The eggs were kept for six hours in a 0.02 p. 100 colchicine solution, and then dissected for removal of the embryo in 0.7 p. $100 \mathrm{NaCl}$. Their tail was submitted to a hypotonic treatment (in distilled water) lasting 15 minutes, fixed in ethanol-acetic acid $(3: 1)$ for 3 minutes, and rinsed in distilled water. The tail epithelium was gently dissociated on the slide in a drop of 50 p. 100 acetic acid.

\section{Fingerlings}

They were kept swimming for 15 hours in a 0.01 p. 100 colchicine solution. After killing, the gills were removed, put in distilled water for 45 minutes, fixed 3 minutes and then dissociated on the slide.

In both cases, the dissociated cells were squashed under a coverlip that was immediately removed in 50 p. 100 acetic acid; after rinsing and drying, the slides were stained in 4 p. 100 Giemsa for 10 minutes.

\section{E. Biochemical studies}

Starch gel electrophoresis of muscle proteins was performed on 20 presumed 7- and 5-month-old triploid hybrids from CS3 and BW3 groups, respectively. The parents of CS groups were also studied. Electrophoretic conditions were described elsewhere (GUYOMARD, 1981).

\section{Results}

\section{A. Viability of diploid and triploid groups}

Mortalities during the experiment are recorded in table 1. 5 periods were studied :

$P 1$ : from fertilization to the end of incubation $\left(D_{0}-D_{30}\right)$,

P 2 : hatching period $\left(D_{31}-D_{43}\right)$,

P 3 : resorption of the yolk sac $\left(D_{44}-D_{t 3 \theta}\right)$,

P 4 : feeding start $\left(D_{61}-D_{105}\right)$,

P 5 : $2^{\text {nd }}$ and $3^{\text {rd }}$ months of feeding $\left(D_{106}-D_{161}\right)$.

Results can be summarized as follows : 


\section{TABLE 1}

Mortality rates from 0 to 161 days for the 8 groups (in percentage of survivors at the beginning of each period).

Taux de mortalité de 0 à 161 jours pour les 8 groupes étudiés (rapportés au nombre de survivants au début de chaque période).

\begin{tabular}{|c|c|c|c|c|c|c|c|}
\hline \multirow{2}{*}{$\begin{array}{c}\text { Group } \\
2=\text { control } \\
3=\text { thermal } \\
\text { shock }\end{array}$} & \multirow[b]{2}{*}{$\begin{array}{c}\text { Male } \\
\text { species }\end{array}$} & \multirow{2}{*}{$\begin{array}{l}\text { Initial } \\
\text { number } \\
\text { of eggs }\end{array}$} & \multicolumn{5}{|c|}{ Mortality rate $(\%)$} \\
\hline & & & $\begin{array}{c}\mathrm{P} 1 \\
\mathrm{D}_{0}-\mathrm{D}_{\mathrm{s} 0}\end{array}$ & $\begin{array}{c}P 2 \\
D_{:: 1}-D_{43}\end{array}$ & $\begin{array}{c}P 3 \\
D_{1 k}-D_{(k)}\end{array}$ & $\begin{array}{c}\text { P4 } \\
\mathrm{D}_{61}-\mathrm{D}_{105}\end{array}$ & $\begin{array}{c}\text { P5 } \\
\mathrm{D}_{108}-\mathrm{D}_{101}\end{array}$ \\
\hline $\begin{array}{l}\text { RA2 } \\
\text { RA3 }\end{array}$ & $\begin{array}{c}\text { Rainbow } \\
\text { trout }\end{array}$ & $\begin{array}{l}643 \\
764\end{array}$ & $\begin{array}{l}12.6 \\
40.1\end{array}$ & $\begin{array}{l}3.0 \\
6.1\end{array}$ & $\begin{array}{l}19.5 \\
43.5\end{array}$ & $\begin{array}{l}20.0 \\
30.9\end{array}$ & $\begin{array}{l}8.2 \\
3.6\end{array}$ \\
\hline $\begin{array}{l}\text { BW2 } \\
\text { BW3 }\end{array}$ & $\begin{array}{l}\text { Brown } \\
\text { trout }\end{array}$ & $\begin{array}{r}473 \\
1073\end{array}$ & $\begin{array}{l}23.1 \\
17.3\end{array}$ & $\begin{array}{l}2.7 .2 \\
13.3\end{array}$ & $\begin{array}{l}99.3 \\
45.9\end{array}$ & $\overline{28.9}$ & $\overline{10.5}$ \\
\hline $\begin{array}{l}\text { BO2 } \\
\text { BO3 }\end{array}$ & $\begin{array}{c}\text { Brook } \\
\text { trout }\end{array}$ & $\begin{array}{l}512 \\
878\end{array}$ & $\begin{array}{r}8.6 \\
14.1\end{array}$ & $\begin{array}{l}2.8 \\
5.0\end{array}$ & $\begin{array}{l}66.6 \\
43.6\end{array}$ & $\begin{array}{l}56.8 \\
18.8\end{array}$ & $\begin{array}{l}47.2^{*} \\
11.0\end{array}$ \\
\hline $\begin{array}{l}\text { CS2 } \\
\text { CS3 }\end{array}$ & $\begin{array}{l}\text { Coho } \\
\text { salmon }\end{array}$ & $\begin{array}{l}414 \\
975\end{array}$ & $\begin{array}{l}36.2 \\
30.5\end{array}$ & $\begin{array}{l}24.2 \\
14.4\end{array}$ & $\begin{array}{l}76.5 \\
67.8\end{array}$ & $\begin{array}{l}95.8 \\
55.6\end{array}$ & $\overline{26.5}$ \\
\hline
\end{tabular}

- No survival.

Aucuh survivant.

* Up to 130 days (eliminated thereafter for karyological investigations).

Jusqu'à 130 jours (prélevés pour examens caryologiques).

\section{RA groups}

In the diploid controls, mortalities were low and limited to the resorption and feeding start periods (P3 and P4). By contrast, the RA3 group exhibited quite high mortalities during the incubation period. P3 and P4 were also critical periods. Later on, the survival rate was very high.

\section{BW groups}

The hatching rate of BW2 was very high, but all the fry died before feeding.

The BW3 group exhibited a lower mortality rate during this resorption period. Later on, the survival of the fry was similar to that of the RA2 control group.

\section{BO groups}

In spite of high mortalities during periods P2, P3 and P5, it was possible to obtain a few survivors in the BO2 group on day 130. These survivors were killed for karyological investigations. Survival in the BO3 group was much higher during P3 and similar to the controls during P4 and P5.

\section{CS groups}

Mortalities were high since fertilization in the diploid group, leading to a complete elimination at the end of P4. 
Results were better in the CS3 group. Nevertheless, mortalities were significantly higher than in RA2 controls during all the periods.

Table 2 indicates the results for all the periods relative to the RA2 control group (Normal diploid rainbow trout). It clearly demonstrates the increase in viability resulting from triploidization.

TABLE 2

Relative success of the 7 experimental groups of $D_{16 t}$ (in \% of the diploid rainbow trout control).

Succès relatif des 7 groupes expérimentaux au $161^{e}$ jour (en \% du lot témoin diplö̈de arc-en-ciel).

\begin{tabular}{lc|c|c|c}
\hline \hline Male species & Rainbow trout & Brown trout & Brook trout & Coho salmon \\
\hline Diploid $\ldots \ldots \ldots \ldots \ldots$ & $\begin{array}{c}100 \\
\text { (control) } \\
\text { Triploid } \ldots \ldots \ldots \ldots \ldots\end{array}$ & 0 & $12.3^{*}$ & 0 \\
\hline \hline
\end{tabular}

\section{B. Karyological investigations}

The karyological examinations performed at the tailbud stage revealed the diploidy $(2 n=60)$ of all the embryos in the RA2 and CS2 batches (10 embryos in each batch). By contrast, all the analysed embryos of the heatshocked RA3 and CS3 batches $(20$ embryos in each) proved to be triploid $(3 n=90)$ (fig. 1).

These results were confirmed in survivors three months after fertilization : 15 fingerlings from RA2, 12 from BW3 (fig. 2) and 12 from $\mathrm{BO} 3$ were analysed and provided triploid metaphases. On the other hand, all the analysed survivors in the BO2 group (22 fingerlings) proved to be diploid (fig. 3).

Because of small variations in chromosome counting, it was not possible definitively to conclude on a doubling of the maternal chromosome set in triploid hybrids, even in BW3 and BO3 groups, in which the two parental species exhibited rather different chromosome numbers : $2 n=60,80$ and 84 for rainbow trout (SimoN \& Dollar, 1963), brown trout (NYGRen et al., 1971) and brook trout (UYENo, 1972), respectively.

\section{Biochemical studies}

Four systems, expressed in the muscle, were chosen for hybrid identification : malate dehydrogenase (MDH - B), phosphoglucose isomerase (PGI), coded by two and three loci respectively in the muscle (see MAY, 1980, for a review on genetic basis of isozymes in Salmonids), cathodal muscle proteins and creatine phosphokinase 
(CPK, previously called anodal muscle proteins). Description and genetic interpretation of CP K in salmonids were made by UTTER and al. (1979). These four systems did not show ontogenic changes between end of resorption and adult stage and were already used for diploid hybrid identification (GUYOMARD, 1978).

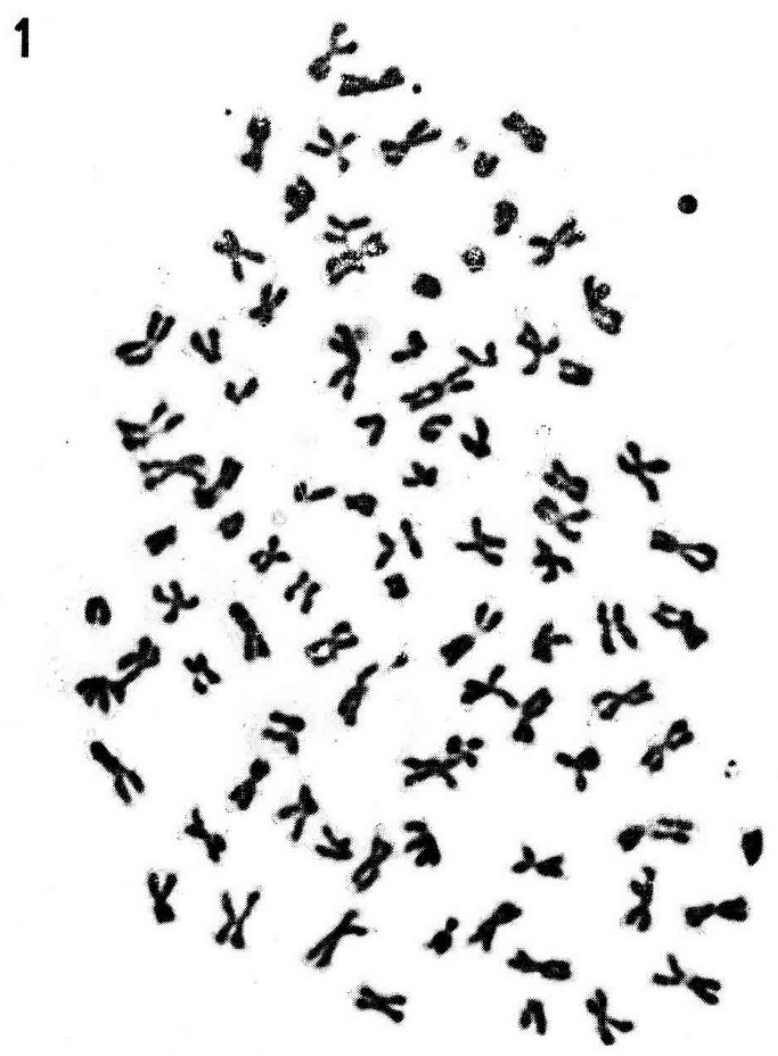

FIG. 1

Metaphase (A) from a triploid hybrid embryo CS3

(Salmo gairdneri o $\times$ Oncorhynchus kisutch of ) $(3 n=89)$

Métaphase d'un embryon triploïde hybride CS3

Fig. 2

Metaphase (A) from a triploid hybrid fingerling $B W 3$

(Salmo gairdneri o $\times$ Salmo trutta ô ) $(3 n=105)$

Métaphase d'un alevin triplö̈de hybride BW3

FIG. 3

Metaphase from a diploid hybrid fingerling $\mathrm{BO} 2$

(Salmo gairdneri o $\times$ Salvelinus fontinalis ô ) $(2 n=70)$

Métaphase d'un alevin diploïde hybride $\mathrm{BO} 2$ 
2

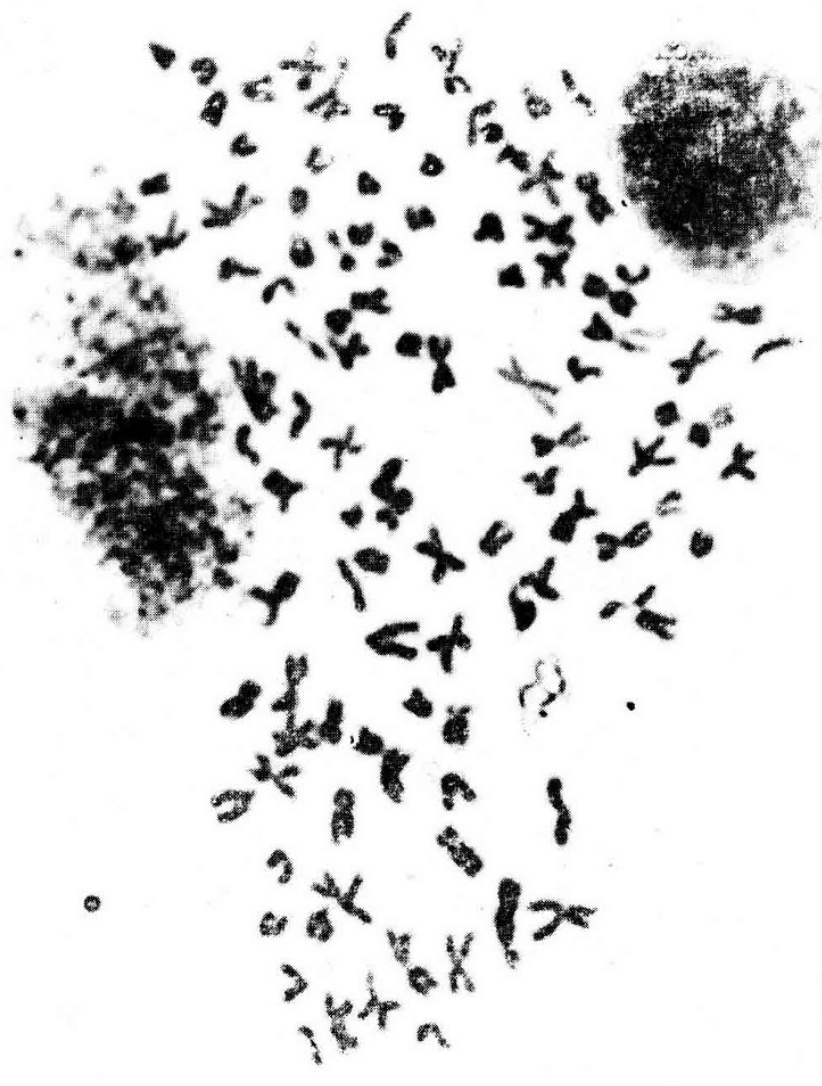

3

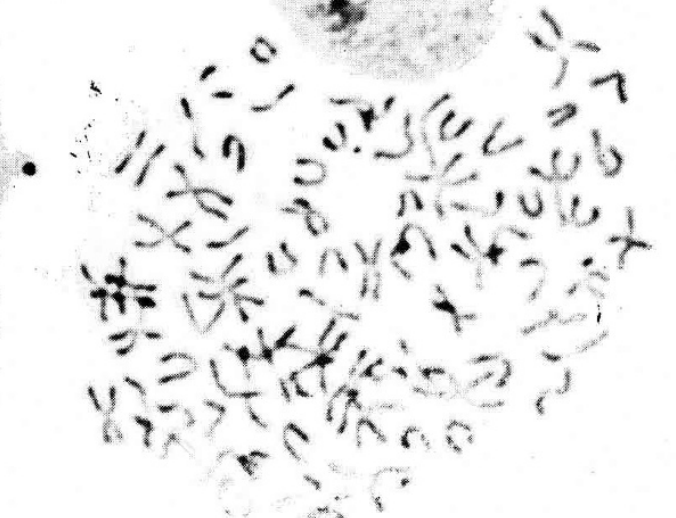


Electrophoregrams of $\mathrm{MDH}$ and muscle proteins are given in figures 4 and 6 and their interpretation in figures 5 and 7 , respectively :

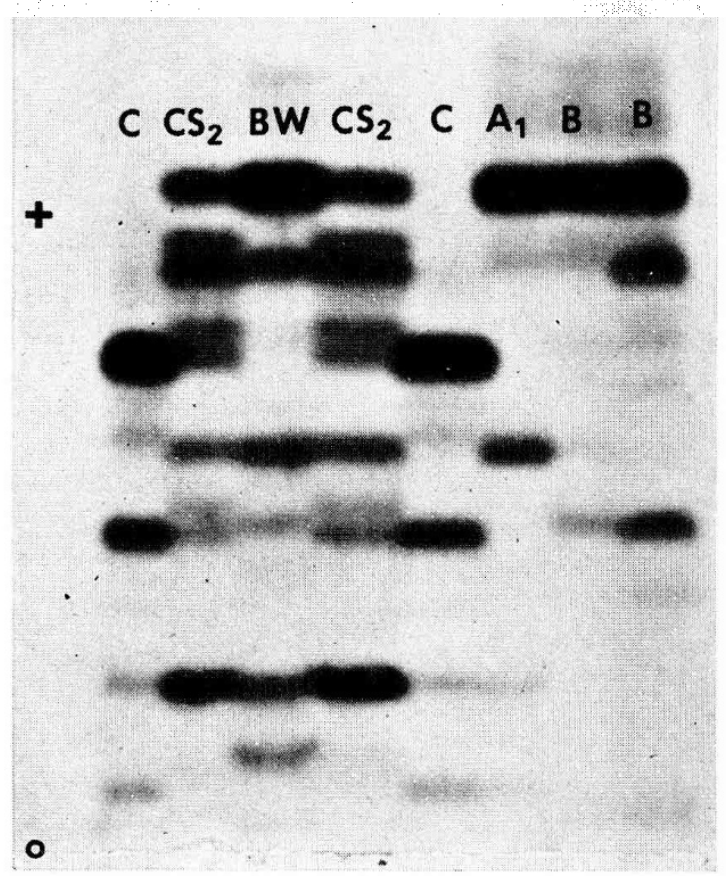

FIG. 4

$M D H$ electrophoregrams in muscle.

C : coho salmon.

Electrophorégrammes $\mathrm{MDH}$ du muscle.

CS : triploid rainbow trout $\times$ coho salmon hybrid.

BW : triploid rainbow trout $\times$ brown trout hybrid.

A : rainbow trout.

B : brown trout.

- Cathodal muscle proteins and PGI were used for the BW group. These two systems were unvariant in parental populations and clearly revealed the hybrid nature of BW fry (fig. 7).

- CPK and MDH appeared to be fitted for studying the CS group. In the case of CPK (fig. 7), the fry were obviously hybrids. Additionally, in the case of $\mathrm{MDH}$, polymorphism of the parents, trigeny at one $\mathrm{MDH}$ locus and the presence of heterozygotes for maternal alleles at this locus (fig. 4 and 5) allowed us to draw two additional conclusions :

(i) the hybrids were triploid;

(ii) triploidy was obtained by a duplication of the maternal genome occurring before the end of meiosis. 


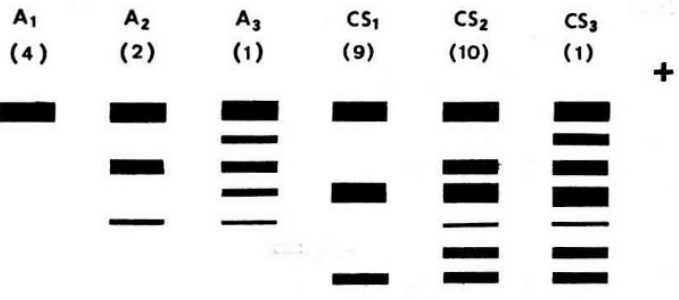

Genotypes:

Rainbow trout

Mdh 3

contribution

Mdh 4

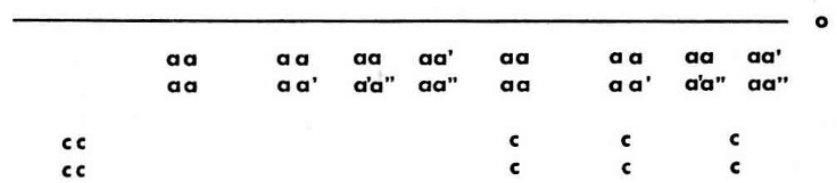

Coho salmon contribution

AA

AA', A"A"

$A^{\prime} A^{\prime}, A^{\prime} C$

$A^{\prime} C$

CC

Mdh 3

Mdh 4

FIG. 5

Interpretation of the $M D H$ electrophoregrams of CS parents and their progeny (same code) : offsprings with phenotype CS1 can be issued from $A_{1}, A_{2}$ or $A_{s}$ females,

phenotype CS2 from $A_{2}$ and $A_{3}$ females; phenotype CS3 only from $A_{3}$ females.

Figures between brackets indicate observed number of each phenotype.

Interprétation des électrophorégrammes de parents CS et de leur descendance (même code) : Les descendances de phénotype CSI peuvent être issues de femelles $A_{1}, A_{\varepsilon}$ ou $A_{s}$. Les phénotypes CS2 de femelles $A_{2}$ ou $A_{s}$.

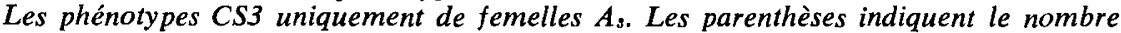
d'individus observés pour chaque phénotype.

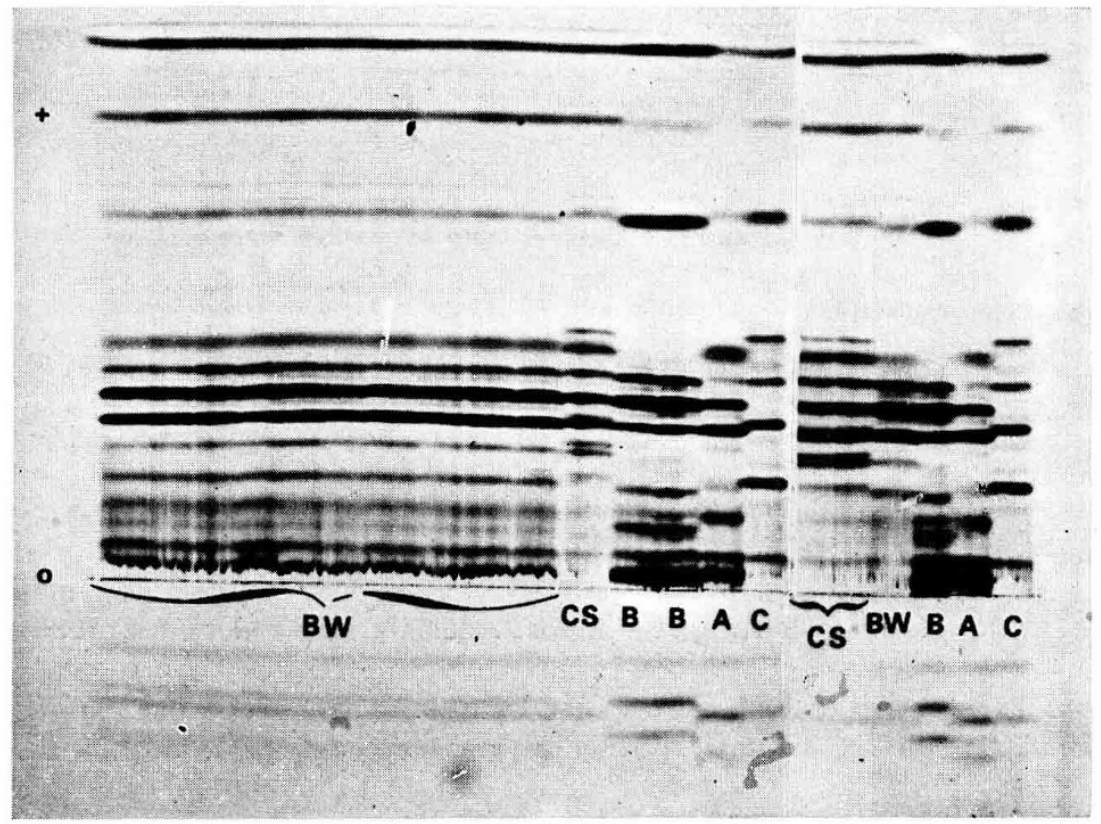

FIG. 6

Muscle protein electrophoregrams.

Same legends as in figure 4.

Electrophorégrammes de protéines du muscle.

Mêmes légendes qu'à la figure 4. 


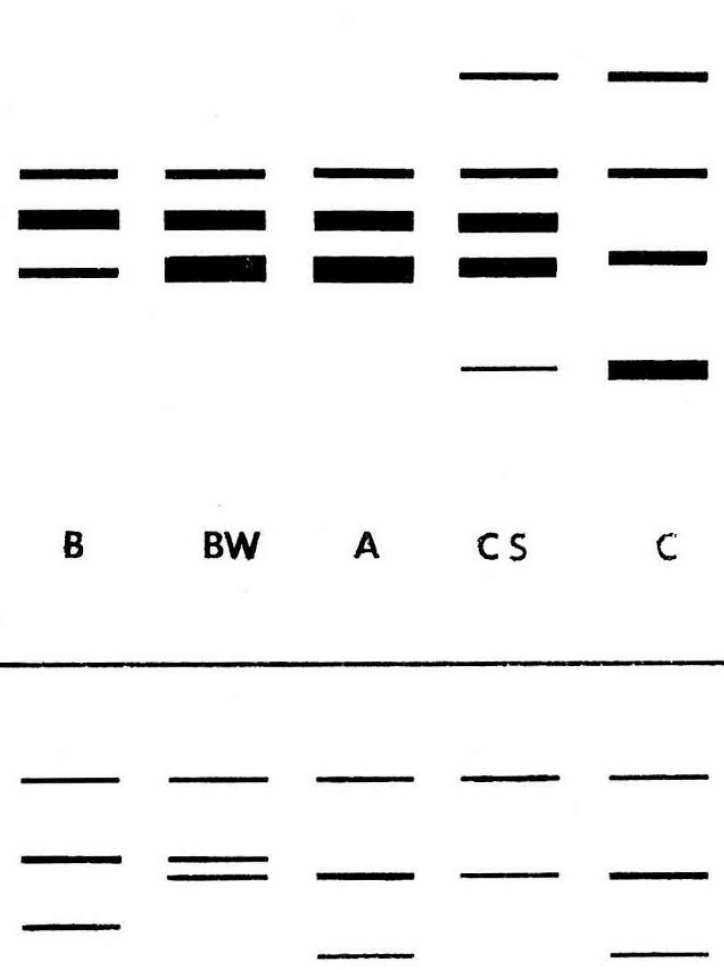

FIG. 7

Interpretation of CPK and cathodal muscle protein electrophoregrams. On anodal part, CPK bands only are represented. Same legends as in figure 4.

Interprétation des électrophorégrammes de CPK et des protéines cathodiques du muscle. $A$ l'anode, représentation uniquement des bandes de CPK Mêmes légendes qu'à la figure 4.

\section{Discussion and conclusions}

(1) Fertilization of eggs by a heterologous sperm may a priori lead to several different events, two of which appear more frequently (see CHEVASsus, 1983 for a review) :

- a gynogenetic or androgenetic development of the egg, which in the case of salmonids results in an unviable haploid embryo (PuRdom, 1969; Arai et al., 1979) ;

- a real karyogamy, resulting in a diploid hybrid genome.

In our experiment, the high hatching rates in the assumed diploid hybrid groups was therefore a good indication for the existence of karyogamy in most of the eggs. Previous biochemical studies (GuYomard, 1978) of hatched fry and our present karyological studies at the tailbud stage corroborate this hypothesis. However, 
the possibility of a low rate of gynogenetic or androgenetic development cannot be excluded (Makeyeva, 1975 ; Stanley, 1976 ; Dimcheva-Grosdanova \& BelCHEVA, 1977). Two kinds of viable genomes might then result from a thermal shock inducing the resorption of the second polar body :

- diploid gynogenetic embryos, which are viable (CHourrout \& QuILleT, 1982). This possibility is all the more likely as thermal treatments may induce both an' inhibition of karyogamy and a retention of the second polar body (RosTAND, 1936) ;

- triploid hybrids, possessing a diploid maternal genome.

According to our biochemical and karyological results, all the studied embryos and fry have an allotriploid constitution and this confirms the very high efficiency of the triploidization treatment (CHOURROUT \& QUILLET, 1982).

(2) Rainbow trout $\times$ coho salmon triploid hybrids have often proved to be heterozygotes for the maternal genome at one MDH locus. According to the classical hypothesis of a retention of the second polar body, a high level of meiotic postreduction may be involved at that locus. This is in good agreement with the results of THORGAARD et al. (1983) and GUYOMARD (1983) on gynogenesis in rainbow trout.

(3) The very low viability of our diploid hybrids is in agreement with the results of several authors (Susuki \& FukUda, 1971; Blanc \& ChEvassus, 1982), even if some viable adults were described in some cases (Buss \& WRIGHT, 1958). However, on account of our preceeding remarks, the true nature of those very few adults should be studied.

(4) The systematical increase in the viability of hybrids resulting from triploidization corroborates the already mentioned results of CAPANNA et al. (1974). More recently, Chourrout \& ItSKovich (1983) in tilapia and Scheerer \& Thorgand (1983) in salmonids obtained similar results.

Additional experiments, especially the study of reciprocal hybrids, would be necessary before explaining and generalizing this result.

(5) By contrast, the viability of autotriploids appears to be lower than that of the diploid control. However, such an observation, especially the higher mortality during the P1 period, was not found again in another experiment (CHOuRrout \& QuilleT, 1982).

(6) Additional studies on survival, growth and reproduction of those triploids have to be made in order to conclude on their practical interest for aquaculture. Their sterility, demonstrated in rainbow trout $\times$ brook trout hybrids (CAPANNA et al., 1974) could be of great interest in some cases (CHEvassus, 1983).

Received March 30, 1983.

Accepted May 31, 1983.

\section{Acknowledgments}

This study was supported by a C.N.E.X.O. grant ref. $81 / 2476$.

We thank Kirsten Rerat and Christiane FaIVET for their help in translating and typing the manuscript. 


\section{References}

Arai K., Onozato H., Yamazaki F., 1979. Artificial androgenesis induced with Gamma irradiation in Masu Salmon, Oncorhynchus masou. Bull. Fac. Fish. Hokkaido Univ., 30, 181-186.

Balsano J.S., Darnell R.M., Abramoff P., 1972. Electrophoretic evidence of triploidy associated with populations of the gynogenetic teleost. Poecilia formosa. Copeia, 1972, 292-297.

Billard R., 1977. Utilization d'un système Tris-Glycocolle pour tamponner le dilueur d'insémination pour truite. Bull. Fr. Pisc., 264, 102-112.

Blanc J.M., Chevassus B., 1982. Interspecific hybridization of Salmonid fish. II - Survival and growth up to the 4th month after hatching in F1 generation hybrids. Aquaculture, 29, 383-387.

Buss K., Wright J.E., 1958. Appearance and fertility of trout hybrids. Trans. Am. Fish Soc., 87, 172-181.

Capanna E., Cataudella S., Volpe R., 1974. Un ibrido intergenerico tra trota iridea e salmerino di fonte (Salmo gairdneri $\times$ Salvelinus fontinalis). Boll. Pesca Piscic. Idrobiol., 29, 101-106.

Chevassus B., 1979. Hybridization in salmonids : results and perspectives. Aquaculture, 17, 113-128.

Chevassus B., 1983. Hybridization in fishes. Aquaculture (in press).

Chourrout D., 1980. Thermal induction of diploid gynogenesis and triploidy in the eggs of the rainbow trout (Salmo gairdneri, Richardson). Reprod. Nutr. Dev., 20, 727-733.

Chourrout D., Quillet E., 1982. Diploid gynogenesis in the rainbow trout : optimization of the heat shock technique; early survival and sex of the progenies. Production of all triploid populations. Theor. Appl. Genet., 63, 201-205.

Chourrout D., ItsKovich J., 1983. Three manipulations permitted by artificial insemination in Tilapia : Induced diploid gynogenesis, production of all-triploid populations and intergeneric hybridization. Proceedings of the International symposium on Tilapia in Aquaculture. Israel, Nazareth, may 8-13, 1983.

Cuellar O., Uyeno T., 1972. Triploidy in rainbow trout. Cytogenetics, 11, 508-515.

Dimcheva-Grosdanova L., Belcheva R., 1977. Embryological and cytogenetical investigations over hybrids F1 between Salmo irideus GIBB $\times$ Salmo trutta m. fario L. Annuaire de l'Université de Sofia, Faculté de Biologie, Livre 1. Zoologie, 70, 85-94.

Guyomard R., 1978. Identification par électrophorèse d'hybrides de salmonidés. Ann. Génét. Sél. anim., 10, 17-27.

GUYOMARD R., 1981. Electrophoretic variation in four french populations of domesticated rainbow trout (Salmo gairdneri). Can. J. Genet. Cytol., 23, 33-47.

GuYOMARD R., 1983. High level of residual heterozygosity in gynogenetic rainbow trout. Theor. Appl. Genet. (in press).

MaKeyeva A.P., 1975. The phenomenon of hybrid gynogenesis in fishes. J. Ichthyol., $15,72-81$.

MaRian T., Krasznai Z., 1978. Karyological investigations on Ctenopharyngodon idella and Hypothalmichthys nobilis and their crossbreeding. Aquacultura Hungarica (Szarvas), 1, 44-50.

MAY B., 1980. The Salmonid genome : evolutionary restructuring following a tetraploid event. Ph.D. Thesis, The Pennsylvania State University, University Park.

Ojima Y., Makino S., 1978. Triploidy induced by cold shock in fertilized eggs of the carp. Proc. Jap. Acad. Sci. B., 54, 359-362.

Purdom C.E., 1969. Radiation-induced gynogenesis and androgenesis in fish. Heredity, 24, 431-444. 
Purdom C.E., 1972. Induced polyploidy in plaice (Pleuronectes platessa) and its hybrid with the flounder (Platichthys flesus). Heredity, Lond., 29, 11-24.

Rostand J., 1936. Gynogenèse par refroidissement des œufs chez Hyla arborea. C.R. Soc. Biol. (Paris), 122, 1012-1013.

Scheerer P.D., ThorgaArd G.H., 1983. Increased survival in trout hybrids by induced triploidy. Can. J. Fish. Aquat. Sci. (in press).

Stanley J.G., 1976. Production of hybrid androgenetic and gynogenetic grass carp and carp. Trans. Am. Fish. Soc., 105, 10-16.

Susuki R., FukUda Y., 1971. Growth and survival of F1 hybrids among salmonid fishes. Bull. Freshwater Fish. Res. Lab. (Tokyo), 21, 117-138.

SVÄrdson G., 1945. Chromosome studies on Salmonidae. Rep. Inst. Freshwater Res., Drottningholm, 23, 1-151.

SWARUP H., 195.8. Production of triploidy in Gasterosteus aculeatus. J. Genet., 56, 129-142.

Thorgand G.H., Gall G.A.E., 1979. Adult triploids in a rainbow trout family. Genetics, 93, 961-973.

Thorgaard G.H., Allendorf F.W., KnUdsen K.L., 1983. Gene centromere mapping in rainbow trout : high interference over long map distances. Genetics, 103, 771-783.

Utter F.M., Allendorf F.W., May B., 1979. Genetic basis of creatine kinase isozymes in skeletal muscle of salmonid-fishes. Biochem. Genet., 17, 1049-1091.

VALENTI R.F., 1975. Induced polyploidy in Tilapia aurea (Steindachner) by means of temperature shock treatment. J. Fish Biol., 7, 519-528.

Vasilev V.P., MakeEva A.P., Ryabov I.N., 1975. On the triploidy of remote hybrids of carp (Cyprinus carpio) with other representatives of cyprinidae. Genetika, 11, 49-56.

Wright J.E., 1955. Chromosome numbers in trout. Progr. Fish. Cult., 17, 172-176. 